\title{
Concurrent Phenologies of Three Semiaquatic Bugs (Heteroptera: Gerridae, Veliidae) on a Small River in Central Illinois, USA
}

\author{
Steven J. Taylor \\ Illinois Natural History Survey, University of Illinois, 1816 S. Oak Street, Champaign, IL 61820-6953, USA \\ Correspondence should be addressed to Steven J. Taylor, sjtaylor@illinois.edu \\ Received 14 March 2009; Accepted 11 May 2009 \\ Recommended by David Denlinger \\ The phenology of three species of Gerroidea (Heteroptera), Metrobates hesperius Uhler (Gerridae), Rhagovelia oriander Parshley \\ (Veliidae), and Rhematobates tenuipes Meinert (Gerridae), was studied on a river in central Illinois (USA). Metrobates hesperius was \\ the most abundant species, and was active from mid-May through mid-October. It was bivoltine and overwintered as eggs. Matinig \\ and oviposition of $M$. hesperius were observed in mid-July. Rhagovelia oriander was present from mid-May to mid-November. This \\ species was bivoltine (or possibly trivoltine), overwintering as eggs. Rheumatobates tenuipes was not active until early August, and \\ was present to mid-November and was univoltine. It overwinters as adults and possibly as nymphs, and may undergo an extended \\ early season diapause. The three species occupied differing microhabitats and differed in periods of peak abundance, with $M$. \\ hesperius being most abundant from mid-May through the first of August, and $R$. tenuipes being most abundant from early August \\ to mid-November.
}

Copyright (C) 2009 Steven J. Taylor. This is an open access article distributed under the Creative Commons Attribution License, which permits unrestricted use, distribution, and reproduction in any medium, provided the original work is properly cited.

\section{Introduction}

The families Gerridae and Veliidae belong to the superfamily Gerroidea [1], a group that usually inhabits the surface film in various microhabitats of lotic and lentic waters, and, in some instances, other terrestrial habitats with high humidity [2]. These animals function as predators and scavengers, typically feeding on other invertebrates trapped in the surface film $[2,3]$. With the exception of a few of the larger species (e.g., Aquarius remigis) the biology and life history of many species have not been thoroughly investigated. In general, species of Gerroidea may be univoltine, bivoltine, or multivoltine [4], overwinter most typically as adults, and oviposit on or in substrates closely tied to their epipleustonic habitat. A number of species exhibit different patterns of wing polymorphism, with macropterous forms dispersing to other habitat patches $[3,5-7]$. In addition to hibernation, some species also undergo diapause, most often in the adult stage (e.g., [3]).

While individual North American gerroid taxa have been the subject of numerous life history studies [4], and several assemblages (sensu [8]) have been examined (e.g., [9-13]), life histories of gerromorphans on rivers are rare, perhaps due to the greater difficulty of sampling these habitats relative to streams and ponds.

I examined Gerroidea species occurring on the Sangamon River in central Illinois, (USA) where the numerically dominant taxa are Metrobates hesperius Uhler, Rhematobates tenuipes Meinert (both Gerridae), and Rhagovelia oriander Parshley (Veliidae). At the study site in Mahomet, Illinois, the Sangamon River drains an area of 93.200 ha, with a base hourly discharge of less than $5 \mathrm{~m}^{3} \mathrm{~s}^{-1}$, but peak discharge in flood events commonly greater than $20 \mathrm{~m}^{3} \mathrm{~s}^{-1}$ and occasionally greater than $80 \mathrm{~m}^{3} \mathrm{~s}^{-1}$ [14]. Tree cover at and near the shoreline is dominanted by Acer saccharinum L. (silver maple), Fraxinus pennsylvanica Marsh. (green ash), and Platanus occidentalis L. (sycamore) $[15,16]$.

\section{Methods}

All sampling was at the Sangamon River at US Highway 150 in Mahomet, Champaign County, Illinois, USA $\left(40.1919^{\circ} \mathrm{N}\right.$, 
$88.3998^{\circ} \mathrm{W}$, elevation $207 \mathrm{~m}$ a.s.l.). Sampling was conducted February 23, April 2, and approximately weekly (every 68 days) from April 25 through November 10, 2000, with one week missed in late June and another missed in early October. The river was too large and deep to effectively sample by wading, and fallen trees, shallow areas, and rocks precluded use of a motorboat. Therefore, sampling was conducted from a whitewater kayak. Sampling was qualitative, consisting of collecting representative samples of all epipleustonic taxa using an aquarium net, with an opening of $15.2 \times 10.2 \mathrm{~cm}$. Samples were collected into 70 $80 \%$ ethanol.

In the laboratory, specimens of $M$. hesperius, $R$. tenuipes, and $R$. oriander - the three dominant gerroids at this sitewere sorted to developmental stage on the basis of body measurements, and larger individuals were sexed. Measurements were made using an Olympus SZH 10 or SZ 60 dissecting microscope with a calibrated ocular micrometer. Measurements included width across eyes and lengths of the pro-, meso-, and metafemora.

Pairwise plotting of the four metrics revealed six distinct size classes of individuals, corresponding to the five nymphal stadia and adults, for each species. These data were then plotted to assess phenology of each of the three species. For all figures, tick marks on top axis (below months) indicate sampling dates. Voucher specimens have been deposited in the INHS Entomology Collections.

\section{Results}

Metrobates hesperius was present from mid-May through mid-October (Figures 1 and 2). First instars were present from mid-May to mid-June, and again in late July and mid-August; second instars, from early June through early July and in early and mid-August; third instars, from midJune through early July and then from late July through mid-August, with a small number of individuals in midSeptember; fourth instars, from mid-June through midAugust, with fewer in mid-July through early August, suggesting two peaks of abundance; and fifth instars from mid-June through mid-August, and again in late September.

Adults appeared in early July and were present through mid-October. All adults were apterous. I observed adults depositing eggs on the lower surface of floating $P$. occidentalis and $A$. saccharinum leaves on 11 July, and 46 eggs on one $P$. occidentalis leaf were collected on that date. Adults were observed aggregating on at least 10 leaves (both green (fresh) and brown (decaying)) floating down current, aggregations numbering 5 to 15 individuals, apparently with males mating, or attempting to mate, with females, and females also ovipositing. They also aggregated in a similar manner around floating bits of bark.

Rhagovelia oriander was present from mid-May through the end of sampling in mid-November (Figures 3 and 4). First instars were present in mid- and late May and in mid-July; second instars, in mid-May and mid-August; third instars, in early June and late July; fourth instars, in early and from mid-June through early August; fifth instars,

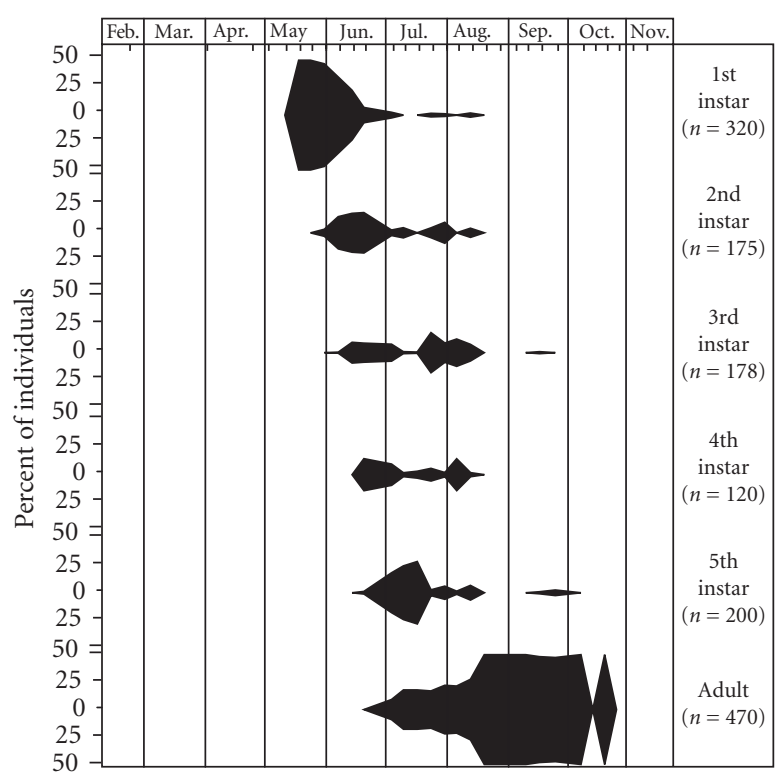

Figure 1: Percent of individuals of Metrobates hesperius in each stage on each sample date.

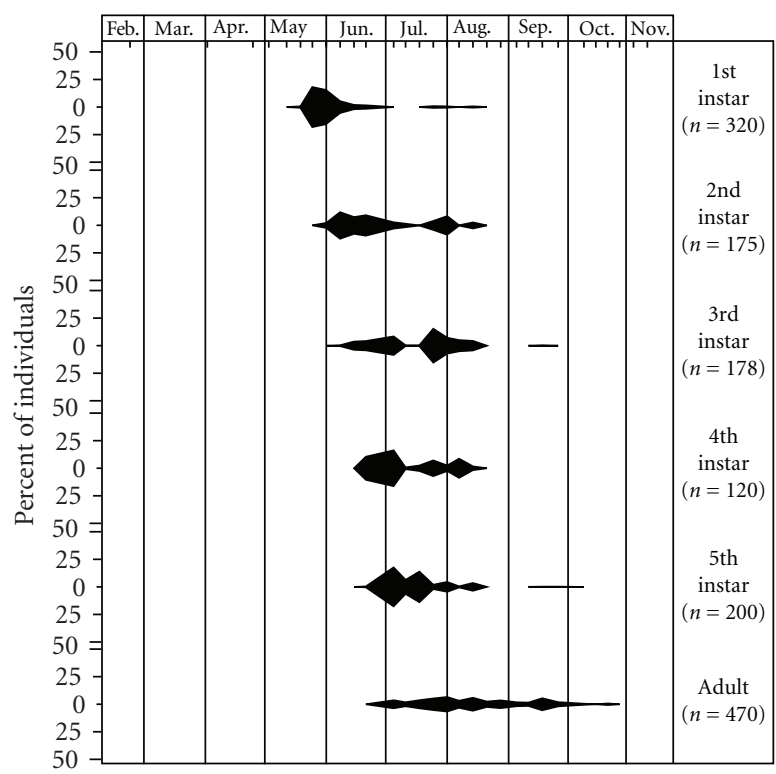

Figure 2: Percent of individuals of Metrobates hesperius of same stage across all sample dates.

from early to mid-June, mid-July to mid-August, and in mid-September. Although adults were present continuously from mid-June through mid-November, a peak from midJune through mid-July is easily distinguishable from the later season adults. Only one macropterous individual was collected (21 October, an adult female), the remaining adults were apterous.

Rheumatobates tenuipes was present from early August through the end of sampling in mid-November (Figures 5 and 6). First instars were present in early and late August; second instars, from early through late August; third instars, 


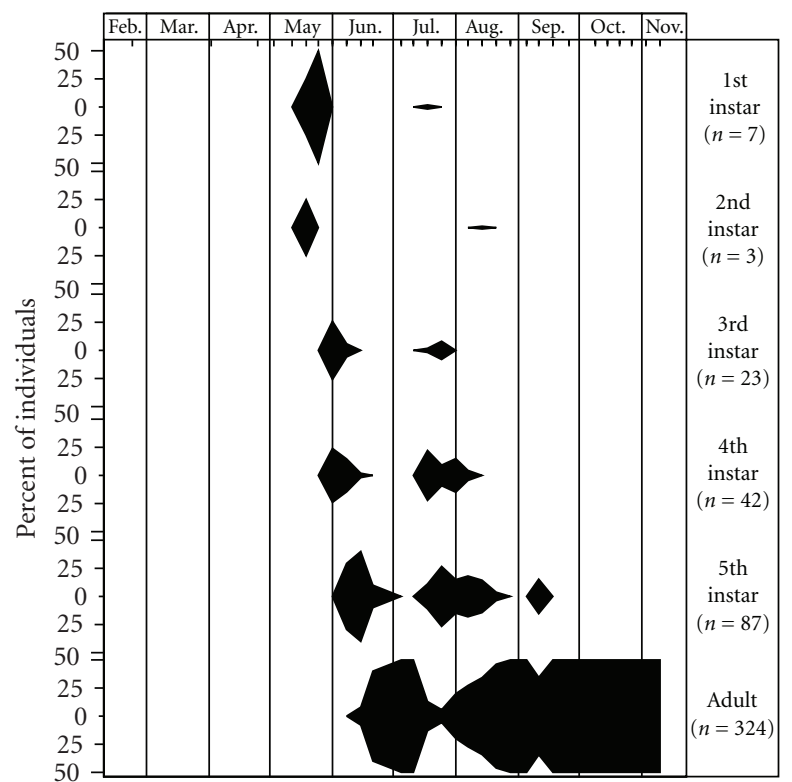

FIgURE 3: Percent of individuals of Rhagovelia oriander in each stage on each sample date.

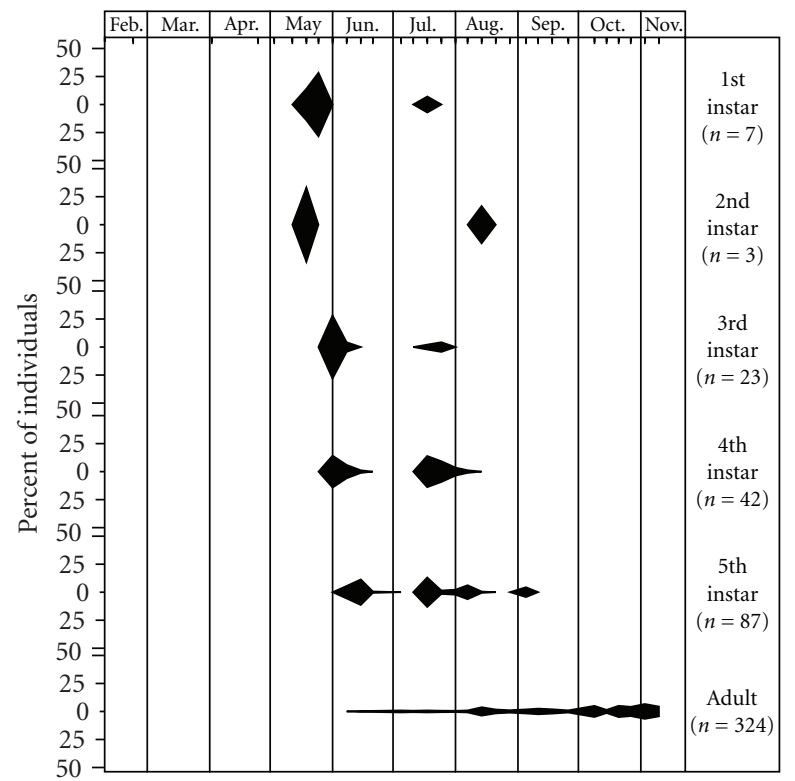

Figure 4: Percent of individuals of Rhagovelia oriander of same stage across all sample dates.

from early August through mid-September; fourth instars, from early August through mid-September, with a second peak from late August through early November; fifth instars were present from early August through mid-September and in late September. Adults were present from early August through mid-November, and were present a week before first-third instars were recorded. All adults were apterous, except for one female collected on August 7, and three females collected on August 14. Several adult females

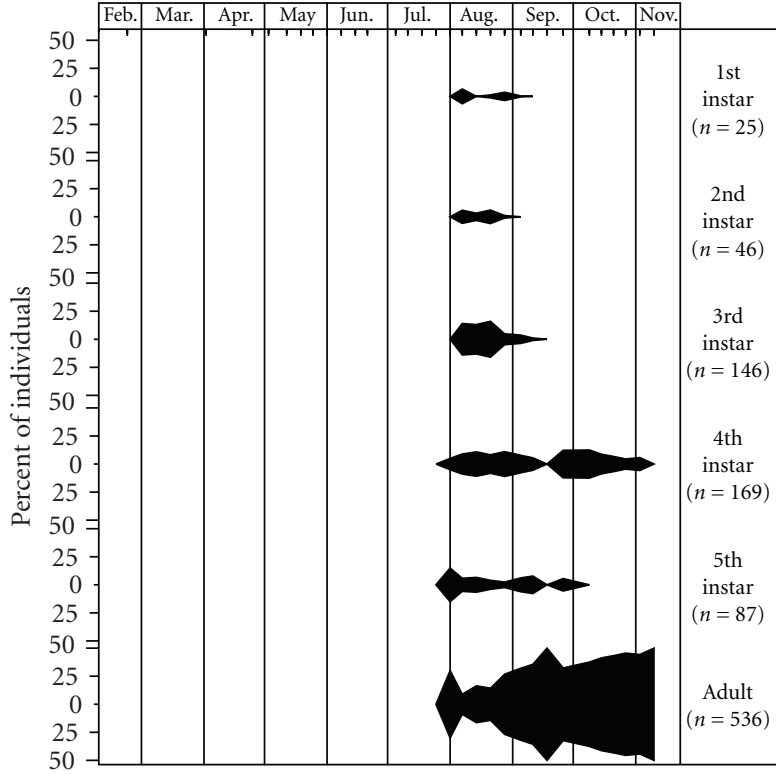

FIGURE 5: Percent of individuals of Rheumatobates tenuipes in each stage on each sample date.

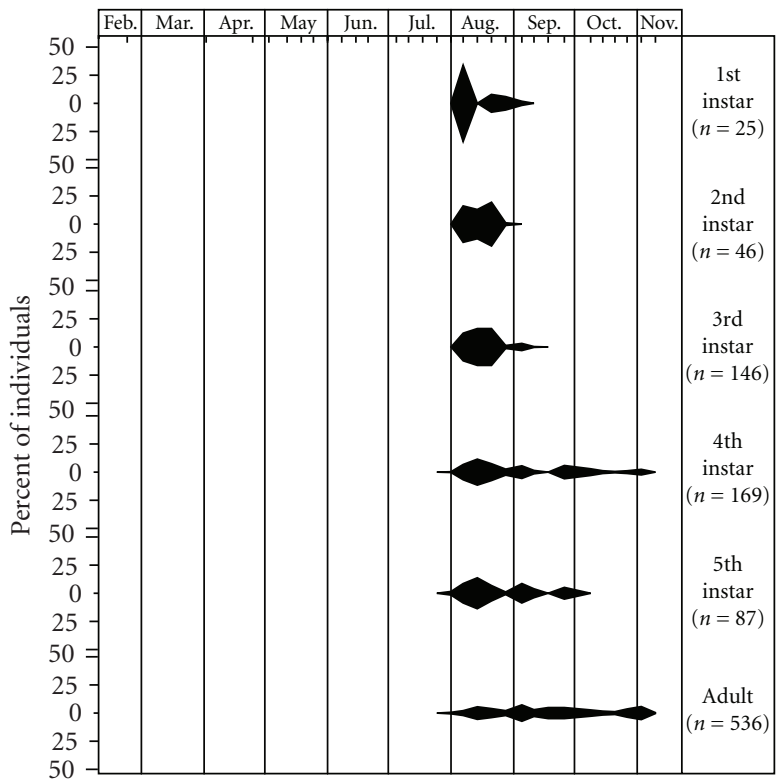

FIGURE 6: Percent of individuals of Rheumatobates tenuipes of same stage across all sample dates.

collected on these two dates were visibly hypogastric (August $7, n=8$; August $14, n=6$ ), indicating that they were about to oviposit.

From early August through mid-October, all three species were active concurrently (Figures 7 and 8). Metrobates hesperius was the numerically dominant gerromorphan on the river from mid-May through the first of August (Figures 7 and 8). From early August to nearly the end of sampling, $R$. tenuipes was numerically dominant. Rhagovelia oriander 


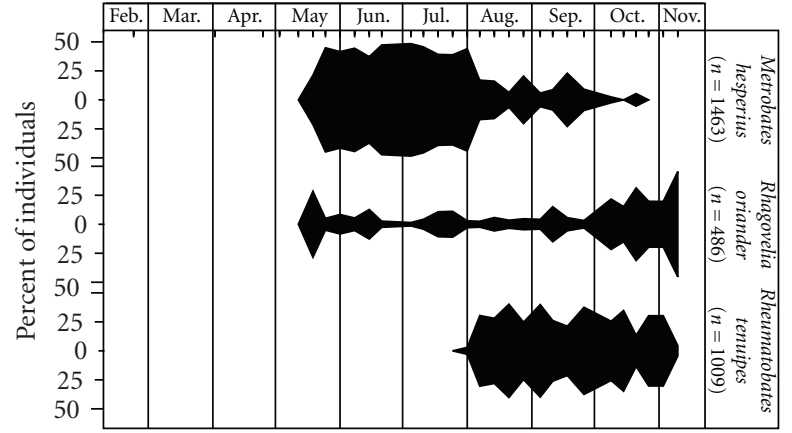

Figure 7: Percent of total individuals of each species (Metrobates hesperius, Rhagovelia oriander, and Rheumatobates tenuipes) on each sample date.

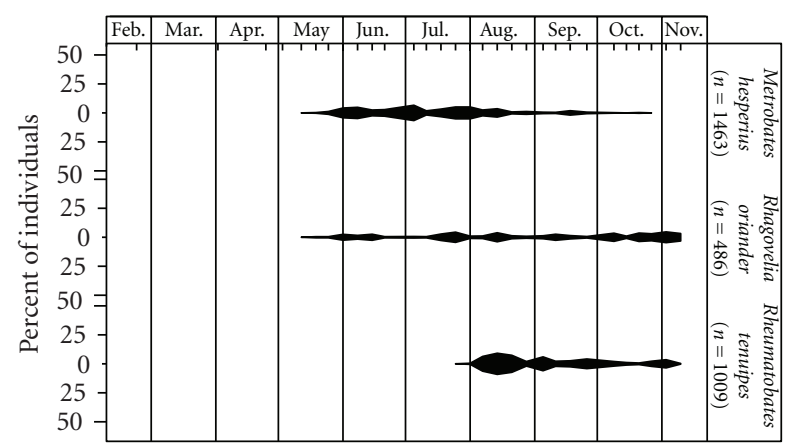

Figure 8: Percent of total individuals of each species (Metrobates hesperius, Rhagovelia oriander, and Rheumatobates tenuipes) across all sample dates.

became increasingly abundant beginning in early October, and remained abundant through the end of sampling in midNovember.

Metrobates hesperius was generally observed in large numbers on open, visibly flowing portions of the river. In July, adults appeared to aggregate in shadows cast by overhanging trees, rather than in direct sunlight, moving to well-lit areas only when approached (in a kayak), and gradually reassembling in the shade following such disturbances. Rhagovelia oriander was always found just downstream of obstructions (fallen logs, limbs, rocks) in association with eddies adjacent to rapidly flowing water. Rheumatobates tenuipes was found primarily along shaded banks, with little or no detectable flow. At low water levels, banks were undercut with many exposed tree roots, and, under these conditions, $R$. tenuipes was commonly found on the water surface up under the banks of the river.

\section{Discussion}

Metrobates hesperius is bivoltine in central Illinois, with a possible much smaller third generation. The present data suggest that this species overwinters as eggs. The seasonal occurrence of $M$. hesperius in the present study also is consistent with earlier observations [17-21], although in southeastern Louisiana Ellis [22] reported collections (stage not indicated) as late as November. Oviposition on organic materials floating down river in the current could function as a means of dispersal in the egg stage.

Rhagovelia oriander was found from May into November in central Illinois, which is generally consistent with previously reported seasonal data [23-25], although Bacon [23] also reported apterous males in April. This species is bivoltine in central Illinois, overwintering in the egg stage. From mid-September through mid-November, only adults of $R$. oriander were present. Unlike the European Velia caprai Tamanini, which can overwinter as both eggs and adults [26], $R$. oriander appears to overwinter exclusively in the egg stage.

Reumatobates tenuipes appears to be univoltine in central Illinois, overwintering as adults and possibly as nymphs, but the September to November peak of fourth instars suggests there could be a second generation, with early instars missed in sampling. I found $R$. tenuipes from early August to early November, and this is consistent with most literature records, which are primarily from September and October $[18,20]$. However, Bobb [27] reported nymphs and adults somewhat earlier in Virginia, in early June. The status of $R$. tenuipes earlier in the season is unclear, but it is possible that the species is in summer diapause (aestivation) during April-July, or that its appearance in August could represent immigration from other habitats. The presence of fourth and fifth instar nymphs in early August, however, suggests immigration does not account for the observed pattern.

All three of the Gerroidea species in this study ( $M$. hesperius, $R$. tenuipes, and $R$. oriander) commonly have been reported from large streams and rivers [17-21, 24, 25, 27-29]. While several studies have reported these species together in the same habitats $[12,13,17]$, their cooccurrence likely depends on a variety of interacting factors (e.g., $[3,13$, 30]).

This study fills a gap in the literature by providing data on concurrent phenologies of these cooccurring species. These data provide an example in which, when the three species cooccur, the taxa appear to partition the small river habitat both in space-position on river-and time, with differing seasonal periods of peaks abundance. Such differences in seasonality and microhabitat might relate to interspecific interactions such as competition or to differing adaptations to the environment [31]. Whether these cooccuring Gerroidea species have adapted to coexist in response to intraspecific interactions or as differing adaptations to the physical environment remains open to study by future workers interested in phenologies and life history strategies of these species.

\section{Acknowledgments}

I thank Vanessa R. Block, Sarah Reisse, Reeba Oman, Amélie Perin, Erin Raboin, and Kristi Moss for help with sample sorting and stage determination. Lara Hitchcock and Barb Coons assisted with fieldwork. Chris Dietrich and Paul Tinerella kindly reviewed an early version of this manuscript. 


\section{References}

[1] R. T. Schuh and J. A. Slater, True Bugs of the World (Hemiptera: Heteroptera): Classification and Natural History, Cornell University Press, Ithica, NY, USA, 1995.

[2] N. M. Andersen, The Semiaquatic Bugs (Hemiptera, Gerromorpha). Phylogeny, Adaptations, Biogeography and Classification, vol. 3 of Entomonograph, Scandinavian Science Press, Klampenborg, Denmark, 1982.

[3] J. R. Spence and N. M. Anderson, "Biology of water striders: interactions between systematics and ecology," Annual Review of Entomology, vol. 39, pp. 101-128, 1994.

[4] A. H. Saulich and D. L. Musolin, Seasonal Development of Aquatic and Semiaquatic True Bugs (Heteroptera), St. Petersburg University Press, St. Petersburg, Russia, 2007.

[5] N. M. Andersen, "The evolution of wing polymorphism in water striders (Gerridae): a phylogenetic approach," Oikos, vol. 67, no. 3, pp. 433-443, 1993.

[6] J. R. Spence, "The habitat templet and life history strategies of pondskaters (Heteroptera: Gerridae): reproductive potential, phenology and wing dimorphism," Canadian Journal of Zoology, vol. 67, no. 10, pp. 2432-2447, 1989.

[7] J. T. Polhemus and H. C. Polhemus, "Family Gerridae/water striders, pond skaters, wherrymen," in The Semiaquatic and Aquatic Hemiptera of California (Heteroptera: Hemiptera), A. S. Menke, Ed., vol. 21 of Bulletin of the California Insect Survey, pp. 58-69, 1979.

[8] J. E. Fauth, J. Bernardo, M. Camara, W. J. Resetarits Jr., J. Van Buskirk, and S. A. McCollum, "Simplifying the jargon of community ecology: a conceptual approach," The American Naturalist, vol. 147, no. 2, pp. 282-286, 1996.

[9] D. M. Calabrese, "The habitats of Gerris F. (Hemiptera: Heteroptera: Gerridae) in Connecticut," Annals of the Entomological Society of America, vol. 70, no. 6, pp. 977-983, 1977.

[10] J. L. Herring, "The aquatic and semiaquatic Hemiptera of northern Florida-part 4: classification of habitats and keys to the species," Florida Entomologist, vol. 34, no. 4, pp. 146-161, 1951.

[11] G. G. E. Scudder, "Aquatic and semiaquatic Hemiptera of peatlands and marshes in Canada," Memoirs of the Entomological Society of Canada, vol. 140, pp. 65-98, 1987.

[12] S. J. Taylor, Habitat preferences, species assemblages, and resource partitioning by Gerromorpha (Insecta: Heteroptera) in Southern Illinois, with a faunal list and keys to species of the state, Ph.D. dissertation, Department of Zoology, Southern Illinois University, Carbondale, Ill, USA, 1996.

[13] S. J. Taylor and J. E. McPherson, "Gerromorpha (Hemiptera: Heteroptera) in southern Illinois: species assemblages and habitats," The Great Lakes Entomologist, vol. 39, no. 1-2, pp. $1-26,2006$.

[14] D. K. Borah, M. Bera, and S. Shaw, "Water, sediment, nutrient, and pesticide measurements in an agricultural watershed in Illinois during storm events," Transactions of the American Society of Agricultural Engineers, vol. 46, no. 3, pp. 657-674, 2003.

[15] D. T. Bell, "Tree stratum composition and distribution in the streamside forest," American Midland Naturalist, vol. 92, no. 1, pp. 35-46, 1974.

[16] D. T. Bell, F. L. Johnson, and A. R. Gilmore, "Dynamics of litter fall, decomposition, and incorporation in the streamside forest ecosystem," Oikos, vol. 30, no. 1, pp. 76-82, 1978.

[17] D. V. Bennett and E. F. Cook, "The semi-aquatic Hemiptera of Minnesota (Hemiptera: Heteroptera)," Minnesota Agricultural Experiment Station Technical Bulletin, vol. 332, pp. 1-59, 1981.
[18] H. C. Chapman, "Distributional and ecological records for some aquatic and semi-aquatic Heteroptera of New Jersey," Bulletin of the Brooklyn Entomological Society, vol. 54, no. 1, pp. 8-12, 1959.

[19] H. O. Deay and G. E. Gould, "The Hemiptera of Indiana, I. Family Gerridae," American Midland Naturalist, vol. 17, no. 4, pp. 753-769, 1936.

[20] P. D. Kittle, "The biology of water striders (Hemiptera: Gerridae) in Northwest Arkansas," American Midland Naturalist, vol. 97, no. 2, pp. 400-410, 1977.

[21] M. W. Sanderson, "Aquatic and semiaquatic Hemiptera," in Aquatic Insects and Oligochaetes of North and South Carolina, A. R. Brigham, W. V. Brigham, and A. Gnilka, Eds., pp. 6.16.94, Midwest Aquatic Enterprises, Mahomet, Ill, USA, 1982.

[22] L. L. Ellis, "The aquatic Hemiptera of southeastern Louisiana (exclusive of the Corixidae)," American Midland Naturalist, vol. 48, no. 2, pp. 302-329, 1952.

[23] J. A. Bacon, "A taxonomic study of the genus Rhagovelia of the Western Hemisphere," University of Kansas Science Bulletin, vol. 38, no. 1, pp. 695-913, 1956.

[24] R. C. Froeschner, "Contributions to a synopsis of the Hemiptera of Missouri-part V: Hydrometridae, Gerridae, Veliidae, Saldidae, Ochteridae, Gelastocoridae, Naucoridae, Belostomatidae, Nepidae, Notonectidae, Pleidae, Corixidae," American Midland Naturalist, vol. 67, no. 1, pp. 208-240, 1962.

[25] D. A. Polhemus, Systematics of the Genus Rhagovelia Mayr (Heteroptera: Veliidae) in the Western Hemisphere (Exclusive of the Angustipes Complex), Thomas Say Publications in Entomology, Entomological Society of America, Lanham, Md, USA, 1997.

[26] T. Ditrich and M. Papáček, "Effective strategy of the overwintering of semiaquatic bugs: overwintering of Velia caprai (Heteroptera: Gerromorpha: Veliidae)," Journal of Natural History, vol. 43, no. 9-10, pp. 529-543, 2009.

[27] M. L. Bobb, The Aquatic and Semiaquatic Hemiptera of Virginia, vol. 87 of The Insects of Virginia, no. 7, Research Division Bulletin, Virginia Polytechnic Institute and State University, Blacksburg, Va, USA, 1974.

[28] W. L. Hilsenhoff, "Semiaquatic Hemiptera of Wisconsin," Great Lakes Entomologist, vol. 19, no. 1, pp. 7-19, 1986.

[29] P. D. Kittle, "The water striders (Hemiptera: Gerridae) of Arkansas," Proceedings of the Arkansas Academy of Science, vol. 34, pp. 68-71, 1980.

[30] I. Karaouzas and K. C. Gritzalis, "Local and regional factors determining aquatic and semi-aquatic bug (Heteroptera) assemblages in rivers and streams of Greece," Hydrobiologia, vol. 573, no. 1, pp. 199-212, 2006.

[31] H. V. Danks, "Insect life-cycle polymorphism: current ideas and future prospects," in Insect Life-cycle Polymorphism: Theory, Evolution, and Ecological Consequences for Seasonality and Diapause Control, H. V. Danks, Ed., vol. 52 of Entomologica, pp. 349-365, Kluwer Academic Publishers, Dordrecht, The Netherlands, 1994. 

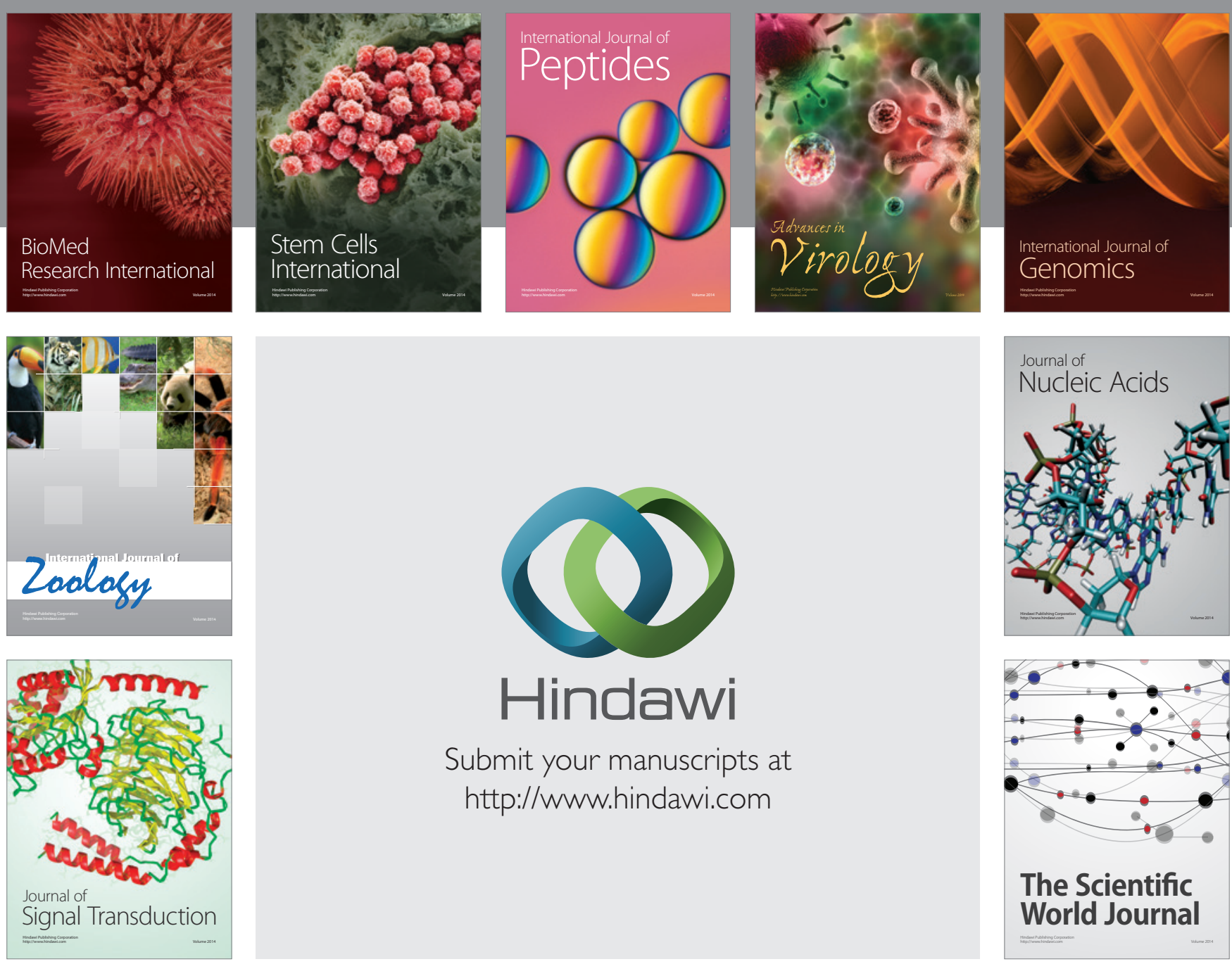

Submit your manuscripts at

http://www.hindawi.com
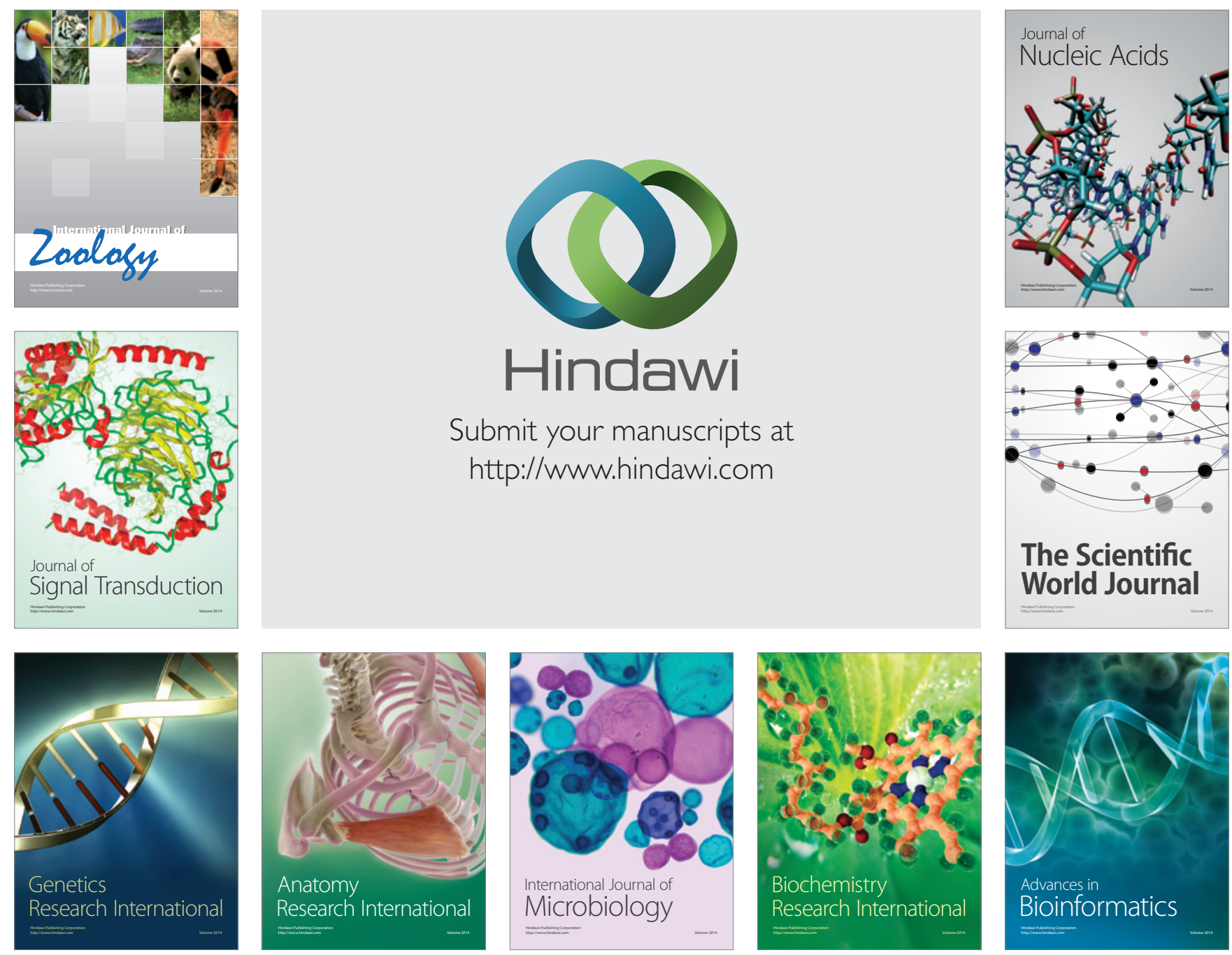

The Scientific World Journal
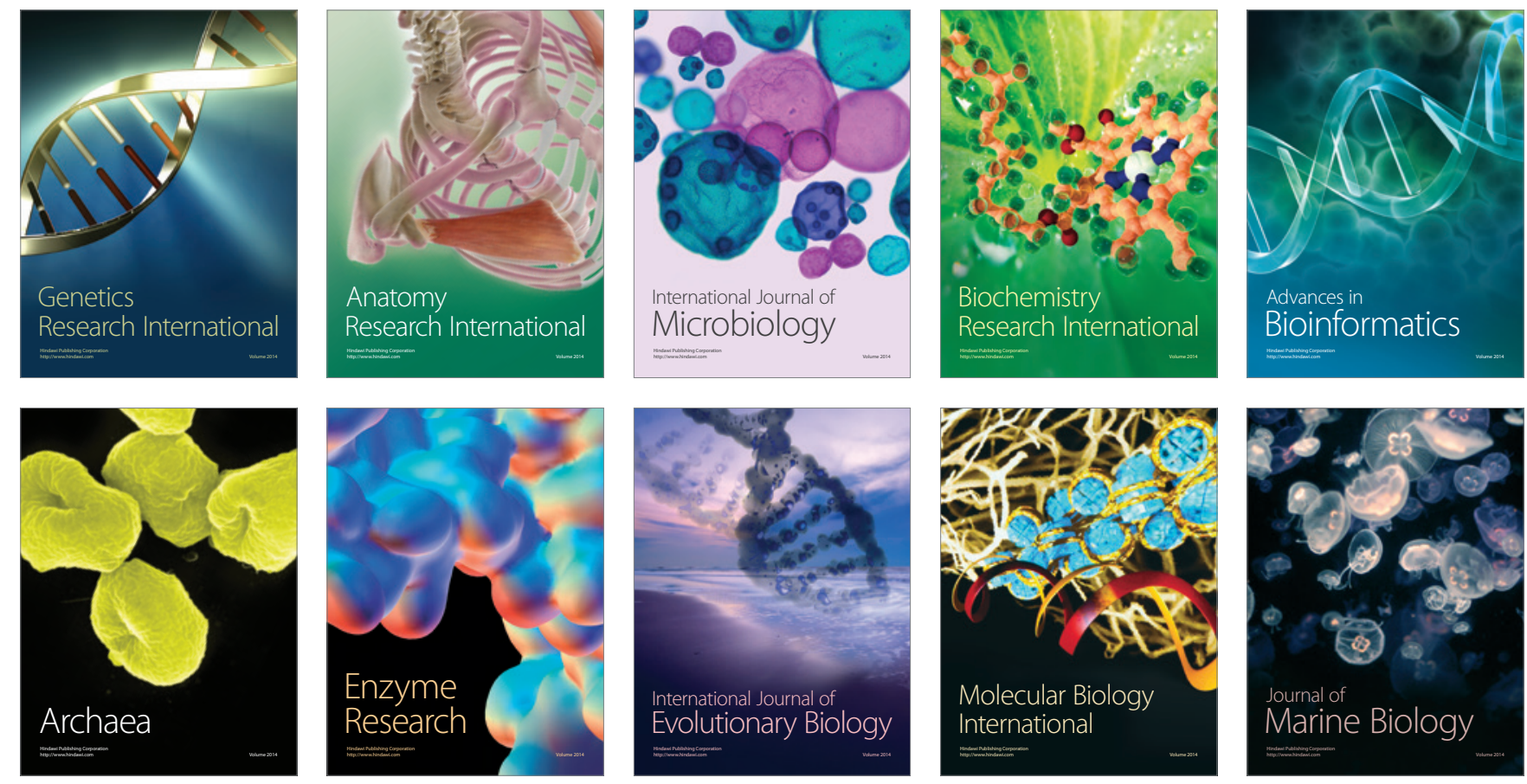